\title{
Overlapping but Distinct Profiles of Gene Expression Elicited by Glucocorticoids and Progestins
}

\author{
Yihong Wan and STEVEn K. NordeEn \\ Department of Pathology and Program in Molecular Biology, University of Colorado \\ Health Sciences Center, Denver, Colorado 80262
}

\begin{abstract}
Glucocorticoids and progestins bind to receptors that share many structural and functional similarities, including virtually identical DNA recognition specificity. Nonetheless, the two hormones mediate very distinct biological functions. For example, progestins are associated with the incidence and progression of breast cancer, whereas glucocorticoids are growth suppressive in mammary cancer cells. To understand the mechanisms that engender biological specificity, we have employed two systematic approaches to identify genes that are differentially regulated by the two hormones. The first strategy is to utilize Affymetrix oligonucleotide arrays to compare glucocorticoid- and progestinregulated gene expression in a human breast cancer cell line. This global analysis reveals that the two hormones regulate overlapping but distinct sets of genes, including 31 genes that are differentially regulated. Surprisingly, the set of differentially regulated genes was almost as large as the set of genes regulated by both hormones. Examination of the set of differentially regulated genes suggests mechanisms behind the distinct growth effects of the two hormones in breast cancer. The differential regulation of four genes representing different regulatory patterns was confirmed by reverse transcription-polymerase chain reaction (RT-PCR) and Northern blot analyses. Treatment with cycloheximide or mifepristone (RU486) indicates that the regulation is a primary, receptor-mediated event. The second strategy is to employ a retroviral promoter trap and Cre/loxP-mediated, sitespecific recombination to identify genes that are differentially regulated by glucocorticoids and progestins. A mouse fibroblast cell line (4F) stably expressing both glucocorticoid receptor (GR) and progesterone receptor (PR) and containing a single copy of a multifunctional selection plasmid was generated. This line was transduced with a self-inactivating retroviral promoter trap vector carrying coding sequences for Cre-recombinase (Cre) in the U3 region. Integration of the provirus places Cre expression under the control of genomic flanking sequence. Activation of Cre expression from integration into active genes results in a permanent switch between the selectable marker genes that convert the cells from neomycin resistant to hygromycin resistant. Selection for hygromycin resistance after hormone treatment yields recombinants in which Cre sequences in the U3 region are expressed from hormone-inducible, upstream cellular promoters. Because Cre-mediated recombination is a permanent event, the expression of the selectable marker genes is independent of ongoing Cre expression. Thus, this system permits the identification of genes that are transiently or weakly induced by hormone. Detailed analyses of genes identified in these studies will furnish a mechanistic understanding of differential regulation by glucocorticoids and progestins.
\end{abstract}




\section{Introduction}

Transcription factors are grouped into families based on their mostconserved feature, usually the DNA binding domain. In many cases, family members share similar, if not indistinguishable, DNA sequence-recognition properties. Thus, a fundamental question in molecular biology concerns the extent to which related factors are functionally redundant in a given cell or tissue and the mechanisms by which factor-specific gene regulation is accomplished.

Glucocorticoid receptor (GR) and progesterone receptor (PR) are closely related members of the steroid receptor family of transcription factors (Thornton, 2001). They share many similar structural and functional characteristics, including DNA sequence recognition specificity (Hynes et al., 1983; Payvar et al., 1983; Scheidereit et al., 1983; Cato et al., 1986; Lieberman et al., 1993). The two receptors associate with a similar complex of molecular chaperones in the absence of hormone (Pratt and Toft, 1997) and with a similar set of coactivators in the presence of hormone (McKenna et al., 1999; Westin et al., 2000). Despite the similarity of the two receptors, the cognate hormones display a very distinct spectrum of physiological actions. Classic actions of glucocorticoids include regulation of metabolism, inhibition of inflammation and the immune system, and suppression of bone formation (Porterfield, 1996). The major physiological role of progestins in the mammal are to establish and maintain pregnancy, to promote lobular-alveolar development in the mammary gland, and to suppress milk protein synthesis before parturition (Graham and Clarke, 1997). Even in tissues that express both GR and PR, these two hormones may exert opposite biological actions. For example, in bone, glucocorticoids stimulate bone resorption (Lane and Lukert, 1998; Rackoff and Rosen, 1998; Ziegler and Kasperk, 1998), while progestins prevent bone loss (Nomura et al., 1989; Prior, 1990). In mammary gland, glucocorticoids promote milk protein synthesis and lactation (Doppler et al., 1989; Groner et al., 1994; Groner and Gouilleux, 1995), while progestins inhibit milk production and secretion (Graham and Clarke, 1997). Furthermore, there is an association of progestins with the incidence and progression of breast cancer (Horwitz, 1992), whereas glucocorticoids are growth suppressive in mammary cancer cells (Lippman et al., 1976; Goya et al., 1993).

How can two receptors with such remarkable similarity mediate such dramatically different biological functions? Only a handful of cellular promoters regulated by GR or PR have been identified. Few cellular promoters have been reported to be differentially regulated by GR and PR. Many of the studies on the mechanisms of GR and PR function have utilized the mouse mammary tumor virus (MMTV) promoter. This promoter is induced by both steroids under most circumstances, although chromatin environment may differentially influence MMTV induction by the two hormones by mechanisms as yet poorly understood 
(Lambert and Nordeen, 1998). Understanding the basis of the distinct physiology of glucocorticoids and progestins is severely limited by the paucity of genes and promoters identified to be differentially regulated by the two receptors. In this review, we summarize two systematic approaches that we have employed to address this void: an Affymetrix microarray analysis and a Cre/loxP-mediated retroviral promoter-trapping strategy. The systematic identification of differentially regulated genes reveals potential avenues of differential regulation of cell growth by the two hormones and opens a new avenue for future studies on the molecular mechanisms underlying hormone-specific gene regulation.

\section{Affymetrix Oligonucleotide Array Analysis}

\section{A. OVERLAPPING BUT DISTINCT GENE REGULATION PROFILES BY GLUCOCORTICOIDS AND PROGESTINS}

To understand the basis of distinct actions of glucocorticoids and progestins in a tissue such as the mammary gland, where both receptors are expressed, and especially to identify genes that are differentially regulated by the two hormones, we performed microarray analysis of gene expression in the human breast cancer cell line T47D/A1-2. T47D/A1-2 cells express comparable levels of GR and PR (Nordeen et al., 1989). Total RNA was isolated from cells treated with vehicle, dexamethasone (Dex, $100 \mathrm{nM})$, or R5020 $(10 \mathrm{nM})$ for 2 or 6 hours. Probes generated from $10 \mu \mathrm{g}$ of this RNA were hybridized to Affymetrix HuGeneFL Arrays to analyze expression of 5600 full-length human genes. In each single array hybridized with cRNAs from T47D/A1-2 cells, 30-40\% of the genes exhibit detectable expression.

Figure 1 depicts the set of genes regulated by glucocorticoids and by progestins and the relationship between the two. Genes were included if the GeneChip software called at least a 3-fold change at one or both time points. In addition, the higher value had to be scored as "present." Of 5600 genes analyzed, 70 were induced by the glucocorticoid, Dex, at either 2-hour or 6-hour treatment, and 47 were induced by the progestin, R5020. Of these, 25 were induced by both hormones (Table I). The number of genes downregulated 3-fold by glucocorticoids and progestins was remarkably similar, 33 and 34, respectively, but only 12 of these were downregulated by both hormones by more than 3 -fold (Table II). Most of the regulated genes identified had not been previously described to be regulated by either glucocorticoids or progestins and therefore represent novel hormone-regulated targets. Novel hormone-regulated targets identified in this study will enhance our understanding of the role of these two hormones as both physiological regulators and pharmacological agents.

Of particular interest for our studies, 31 genes have been identified to be differentially regulated by the two hormones by more than 3 -fold (Table III). In 


\section{In T47D/A1-2 Breast Cancer Cells (GR+/PR+): \\ Up-regulated $>3$ fold Down-regulated $>3$ fold
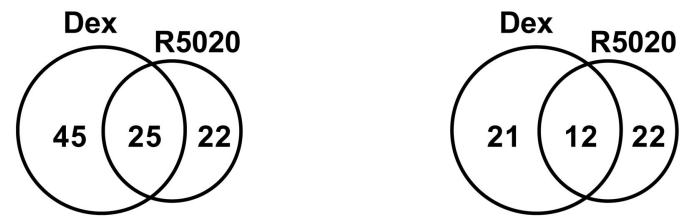

\section{Differentially Regulated by $>3$ fold: $\mathbf{3 1}$ genes}

FIG. 1. Diagrammatic representation of the sets of genes regulated by glucocorticoids and by progestins. Total RNA was analyzed by Affymetrix oligonucleotide arrays. Data were analyzed using GeneChip Expression Analysis software. Shown are the numbers of genes up- or downregulated by either hormone by more than 3 -fold and the number of genes differentially regulated by the two hormones by more than 3 -fold.

light of the paucity of genes described to be differentially regulated by the two hormones, it was surprising that the number of genes differentially regulated by more than 3-fold (31) approached the number regulated by both by more than 3 -fold (37). Each set represents about $1.5-2 \%$ of the genes whose expression could be detected. These results show that glucocorticoids and progestins regulate overlapping but distinct sets of genes.

\section{B. CONFIRMATION OF DIFFERENTIAL REGULATION WITH REVERSE TRANSCRIPTION-POLYMERASE CHAIN REACTION (RT-PCR) AND NORTHERN BLOT ANALYSES}

Four differentially regulated genes identified by the array analysis as representing different patterns of regulation were selected for further analysis. G0S8 (also known as RGS2, regulator of G-protein signaling 2) is specifically induced by Dex but not by R5020 (Table III), whereas the promyelocytic leukemia zinc finger protein gene (PLZF) was preferentially induced by glucocorticoids. In contrast, the gene encoding the $\beta \mathrm{B}$ subunit of inhibins and activins (INHBB) is specifically induced by progestins. The IEX-1/Dif-2 gene represents yet another pattern of differential regulation. The array results suggest that expression of IEX-1/Dif-2 is specifically repressed by glucocorticoids. The possible contribution of differential expression of these genes to differential effects of glucocorticoids and progestins will be discussed later.

To determine whether the array analysis gave a true reflection of the expression pattern of these genes, mRNA levels were quantified by both semi- 
TABLE I

Genes Upregulated by Both Dex and R5020 by More Than 3-Fold

\begin{tabular}{|c|c|c|c|c|c|}
\hline \multirow[b]{2}{*}{ Probe set } & \multirow[b]{2}{*}{ Description } & \multicolumn{4}{|c|}{ Fold change } \\
\hline & & $\mathrm{D} 2: \mathrm{V}$ & D6:V & $\mathrm{R} 2: \mathrm{V}$ & $\mathrm{R} 6: \mathrm{V}$ \\
\hline D16227_at & BDP-1, recoverin family, calcium-binding & 1.4 & 8.3 & -2.5 & 5.7 \\
\hline D38037_at & FK506-binding protein $12 \mathrm{kDa}$ homologue & 1.6 & 9.2 & 4.2 & 5.6 \\
\hline D86956_at & KIAA0201 gene & 1.8 & 3.5 & 2 & 3.1 \\
\hline HG4310-HT4580 & Cellular retinol binding protein $\mathrm{Li}$ & 3.6 & 10.7 & 1.5 & 7.3 \\
\hline M14218_at & Argininosuccinate lyase, arginine metabolism & 2.2 & 3.9 & 3 & 2 \\
\hline M83667_rna1_s & NF-IL6-beta protein, C/EBP family & 4.1 & 8.7 & 3.6 & 7.5 \\
\hline U26726_at & 11-beta-hydroxysteroid dehydrogenase type 2 & 7.4 & 27.1 & 6.9 & 21 \\
\hline U36922_at & Forkhead domain protein, transcription factor & 1.5 & 4.9 & 3.1 & 3.2 \\
\hline U42031_at & 54 kDa Immunophilin FKBP54 & 1.7 & 6.3 & 1.5 & 3.8 \\
\hline U54999_at & LGN protein, inhibit $\mathrm{G}$ alpha i2 & 2.1 & 4.2 & 1.9 & 5.1 \\
\hline U62015_at & Cyr61, growth factor-inducible gene & 1.5 & 3.4 & 1.9 & 5.1 \\
\hline U72342_at & Platelet activating factor acetylhydrolase & 3.5 & 3.5 & 3.3 & 2.4 \\
\hline U73524_at & Putative ATP/GTP-binding protein & 5.7 & 6.4 & 4.3 & 4.2 \\
\hline U77456_at & Nucleosome assembly protein 2 & 3.8 & 4.3 & 4 & 7.4 \\
\hline U81554_at & CaM kinase isoform II & 6.3 & 5.4 & 5.4 & 4.2 \\
\hline U81556_at & Hypothetical protein A4 & 5.1 & 3.5 & 4.7 & 4.8 \\
\hline U83461_at & Putative copper uptake protein (hCTR2) & 2.7 & 3.2 & 2.8 & 3.9 \\
\hline U85267_at & Down syndrome candidate region 1 (DSCR1) & 1.6 & 4.7 & 2.4 & 7.7 \\
\hline U85611_at & DNA-PK interaction protein (KIP) & 3.8 & 3.9 & 3.7 & 3.6 \\
\hline U90426_at & Nuclear RNA helicase & 3.5 & 3.3 & 3.3 & 2.3 \\
\hline U90919_at & Clones 23667 and 23775 zinc finger protein & 2.4 & 3 & 2.3 & 3.1 \\
\hline U91316_at & Acyl-CoA thioester hydrolase & 5.5 & 5.8 & 3.3 & 4.2 \\
\hline U91327_at & 12p15 BAC clone CIT987SK-99D8 & 5.4 & 4.3 & 3.7 & 3.2 \\
\hline X60673_rna1 & Adenylate kinase 3 , nucleotide metabolism & 2.9 & 3.2 & 3.3 & 3.2 \\
\hline Z19002_at & PLZF, transcription repressor & 7.3 & 14.4 & 2.9 & 4.5 \\
\hline
\end{tabular}

[Abbreviations: V, vehicle; D2, D6, dexamethasone 2 hr, 6 hr; R2, R6, R5020 2 hr, 6 hr.] 
TABLE II

Genes Downregulated by Both Dex and R5020 by More Than 3-Fold

\begin{tabular}{|c|c|c|c|c|c|}
\hline \multirow[b]{2}{*}{ Probe set } & \multirow[b]{2}{*}{ Description } & \multicolumn{4}{|c|}{ Fold change } \\
\hline & & $\mathrm{D} 2: \mathrm{V}$ & D6:V & $\mathrm{R} 2: \mathrm{V}$ & R6:V \\
\hline AB000584_at & Novel TGF-beta superfamily protein & -1.8 & -20.7 & -1.6 & -20.6 \\
\hline D14695_at & KIAA0025 gene & 1.1 & -3.5 & 1.3 & -3.5 \\
\hline HG2724-HT2820 & Oncogene Tls/Chop, liposarcomas & -1.8 & -14.8 & -1.5 & -21 \\
\hline L07615_at & $\begin{array}{l}\text { Neuropeptide Y receptor Y1, G protein } \\
\text { coupled }\end{array}$ & -1.3 & -3.5 & -1.9 & -4.4 \\
\hline L37347_at & Integral membrane protein, iron uptake & -2.9 & -3 & -2.6 & -3.2 \\
\hline L37882_at & Frizzled gene, receptor for Wnt & -2.4 & -6.7 & -4.6 & -6.8 \\
\hline M88461_s_at & $\begin{array}{l}\text { Neuropeptide Y receptor YY, G protein } \\
\text { coupled }\end{array}$ & -2.2 & -3.2 & -2.6 & -3.2 \\
\hline U07225_at & P2U nucleotide receptor & -1.7 & -4.7 & -1.7 & -4.3 \\
\hline U07358_at & Protein kinase (zpk), a leucine zipper domain & -1.7 & -3.7 & -2.1 & -3.2 \\
\hline U22376_cds2_s & c-myb, transcription factor, proto-oncogene & -1.5 & -5 & -3.3 & -3 \\
\hline U39840_at & Hepatocyte nuclear factor-3 alpha & -1.2 & -3.3 & -2.1 & -3.3 \\
\hline X51630_at & Wilms tumor WT1, tumor suppressor & -1.2 & -3.2 & -1.3 & -3.2 \\
\hline
\end{tabular}

[Abbreviations: V, vehicle; D2, D6, dexamethasone 2 hr, 6 hr; R2, R6, R5020 2 hr, 6 hr.]

quantitative PCR and Northern blot analyses (Wan and Nordeen, 2002b). Both confirmed the selective induction of G0S8/RGS2 by glucocorticoids (Figure 2A). Quantification of the Northern blot showed that Dex treatment led to a more than 20 -fold induction, while R5020 had little effect on transcript levels. As for G0S8/RGS2, the RT-PCR and Northern blot analyses confirm that PLZF is strongly induced by Dex but, unlike G0S8/RGS2, PLZF is also weakly induced by R5020 (Figure 2B). Additionally, the Northern blots indicated that PLZF is expressed as two transcripts, $11 \mathrm{~kb}$ and $9 \mathrm{~kb}$. Both transcripts are differentially induced by Dex. The INHBB gene also is expressed as two transcripts, as had previously been reported for rat INHBB (Feng et al., 1989). Levels of both the 4-kb and 3-kb transcripts were increased by R5020, while Dex had no effect on the larger transcript and downregulated the smaller transcript slightly (Figure $2 \mathrm{C})$. Finally, direct analyses of IEX/Dif-2 gene expression also supported the array data. Dex treatment led to an $80 \%$ downregulation by 6 hours, whereas R5020 treatment resulted in a weak, transient downregulation, with transcript levels returning to control levels by 6 hours (Figure 2D). Previous studies have 
TABLE III

Genes Differentially Regulated by Dex and R5020 by More Than 3-Fold

\begin{tabular}{|c|c|c|c|c|c|c|}
\hline \multirow[b]{2}{*}{ Probe set } & \multirow[b]{2}{*}{ Description } & \multirow{2}{*}{$\begin{array}{l}\text { Difference }^{\mathrm{a}} \\
\mathrm{D}: \mathrm{R}\end{array}$} & \multicolumn{4}{|c|}{ Fold change } \\
\hline & & & $\mathrm{D} 2: \mathrm{V}$ & D6:V & R2:Ṽo & R6:V \\
\hline L13391_at & G0S8, Gqalpha inhibitor & 15.4 & 8.5 & 14.3 & 2.9 & -1 \\
\hline Z19002_at & PLZF, transcription repressor & 9.6 & 7.3 & 14.4 & 2.9 & 4.5 \\
\hline M38258_at & $\begin{array}{l}\text { Retinoic acid receptor } \\
\text { gamma } 1\end{array}$ & 6.5 & -1.6 & -1.2 & -1.6 & -7.3 \\
\hline U75272_s_at & Gastricsin, protein degradation & 6.3 & 4 & 8.4 & -1 & 1.3 \\
\hline S73591_at & $\begin{array}{l}\text { VDUP1, inhibit thioredoxin } \\
\& \text { growth }\end{array}$ & 5.1 & 1.2 & 1.1 & -2.3 & -4.5 \\
\hline U37546_s_at & IAP homolog $\mathrm{C}$ & 4.6 & 1.6 & 4.7 & 2.1 & -1.2 \\
\hline D80010_at & KIAA0188 gene & 4.5 & 2.1 & 3.4 & 1.4 & -1.9 \\
\hline HG3494-HT3688 & Nuclear factor Nf-II6 & 4.2 & -1.1 & 1.4 & -1.2 & -3.1 \\
\hline M77140_at & Pro-galanin, a neuropeptide & 4.1 & 1.2 & 5.9 & 1.6 & 1.4 \\
\hline U15932_at & $\begin{array}{l}\text { Dual-specificity protein } \\
\text { phosphatase }\end{array}$ & 4 & 1.2 & -1 & -3.4 & -2.1 \\
\hline X77777_s_at & VIP receptor related protein & 4 & 3.8 & 10.7 & -1.1 & 1.7 \\
\hline M33317_f_at & $\begin{array}{l}\text { Cytochrome P450IIA4 } \\
\text { (CYP2A4) }\end{array}$ & 3.9 & 4.2 & 2.8 & 1.6 & 2.9 \\
\hline HG4310-HT4580 & $\begin{array}{l}\text { Cellular retinol binding } \\
\text { protein } \mathrm{Li}\end{array}$ & 3.8 & 3.6 & 10.7 & 1.5 & 7.3 \\
\hline U63455_at & Sulfonylurea receptor & 3.5 & 1.5 & 3.6 & 1.3 & 1 \\
\hline X17059_s_at & $\begin{array}{l}\text { Arylamine } \mathrm{N}- \\
\text { acetyltransferase }\end{array}$ & 3.4 & 3 & 2.8 & 1.7 & 1.2 \\
\hline X51956_rna1_at & $\begin{array}{l}\text { ENO2, neuron specific } \\
\text { enolase }\end{array}$ & 3.2 & 1.4 & -1.6 & -1.1 & -4.6 \\
\hline M29874_s_at & $\begin{array}{l}\text { Cytochrome P450-IIB } \\
\text { (hIIB1) }\end{array}$ & -3 & -3.8 & -3.7 & -1.6 & -2 \\
\hline HG110-HT110_s & $\begin{array}{l}\text { Nuclear ribonucleoprotein } \\
\text { A/B }\end{array}$ & -3.4 & -4.8 & 1.1 & -1.4 & 1.3 \\
\hline L13210_at & $\begin{array}{l}\text { Mac- } 2 \text { binding protein, tumor } \\
\text { antigen }\end{array}$ & -3.4 & 1.1 & 1.3 & 3.7 & -3 \\
\hline J03474_at & Serum amyloid A, acute phase & -3.5 & 1.4 & 1.6 & 3.5 & 1.3 \\
\hline
\end{tabular}




\begin{tabular}{|c|c|c|c|c|c|c|}
\hline \multirow[b]{3}{*}{ Probe set } & \multirow[b]{3}{*}{ Description } & \multirow{3}{*}{$\begin{array}{l}\text { Difference } \\
\text { D:R }\end{array}$} & \multirow{2}{*}{\multicolumn{4}{|c|}{ Fold change }} \\
\hline & & & & & & \\
\hline & & & $\mathrm{D} 2: \mathrm{V}$ & D6:V & $\mathrm{R} 2: \mathrm{V} \tilde{\mathrm{n}}$ & R6:V \\
\hline M62783_at & $\begin{array}{l}\text { alpha-N- } \\
\text { Acetylgalactosaminidase }\end{array}$ & -3.9 & -3.6 & -1.2 & 1.1 & -1 \\
\hline U34605_at & $\begin{array}{l}\text { Retinoic acid, interferon- } \\
\text { inducible }\end{array}$ & -3.9 & -3.7 & -2 & -1 & -1.7 \\
\hline U52513_at & Retinoic acid-induced gene $\mathrm{G}$ & -4 & -1.9 & -4.4 & 3.1 & -4.7 \\
\hline M31682_at & $\begin{array}{l}\text { Testicular inhibin beta-B- } \\
\text { subunit }\end{array}$ & -4.5 & 2 & 1.9 & 4.9 & 8.4 \\
\hline M80359_at & Protein p78 & -5 & -3.4 & 1.1 & 1.9 & 1.4 \\
\hline U23070_at & $\begin{array}{l}\text { Putative transmembrane } \\
\text { protein }\end{array}$ & -5 & 1 & -4.2 & 1.9 & 1.2 \\
\hline X51441_at & $\begin{array}{l}\text { Serum amyloid A (SAA), } \\
\text { acute phase }\end{array}$ & -5.1 & -1.5 & 1.1 & 4.1 & 1.3 \\
\hline U48807_at & MAP kinase phosphatase 2 & -5.7 & 1.3 & -3.6 & 1.1 & 1.6 \\
\hline U77735_at & $\begin{array}{l}\text { pim-2 proto-oncogene, Ser/ } \\
\text { Thr kinase }\end{array}$ & -6.2 & 1.5 & 1.1 & 3 & 5.3 \\
\hline S81914_at & $\begin{array}{l}\text { IEX-1/Dif-2, growth factors } \\
\text { inducible }\end{array}$ & -7.3 & -4.8 & -12 & -2.4 & -1.6 \\
\hline M74089_at & $\begin{array}{l}\text { TB1 gene, FAP and } \\
\text { colorectal cancer }\end{array}$ & -10.5 & -8 & 1.2 & 1.3 & 1.2 \\
\hline \multicolumn{7}{|l|}{ controls } \\
\hline X00351_f_at & beta-Actin & -1.4 & 1 & -1.3 & -1.1 & 1.1 \\
\hline U37689_at & RNA polymerase II subunit & 1.2 & 1.1 & -1.1 & -1.1 & 1 \\
\hline
\end{tabular}

[Abbreviations: V, vehicle; D2, D6, dexamethasone 2 hr, 6 hr; R2, R6, R5020 2 hr, 6 hr. ${ }^{\mathrm{a} F o l d}$ difference was calculated using GeneChip algorithms, not a direct ratio of fold changes. The higher value of the two timepoints is shown.]

shown that the Affymetrix oligoarray technology produces highly reliable results, many of which have been confirmed by conventional approaches (Fambrough et al., 1999; Harkin et al., 1999; Jelinsky and Samson, 1999). In this study, for all four genes tested individually, there is excellent agreement between the microarray results and the Northern blot analyses. However, we chose some of the more robustly regulated genes for this analysis. Obviously, there is a greater likelihood 


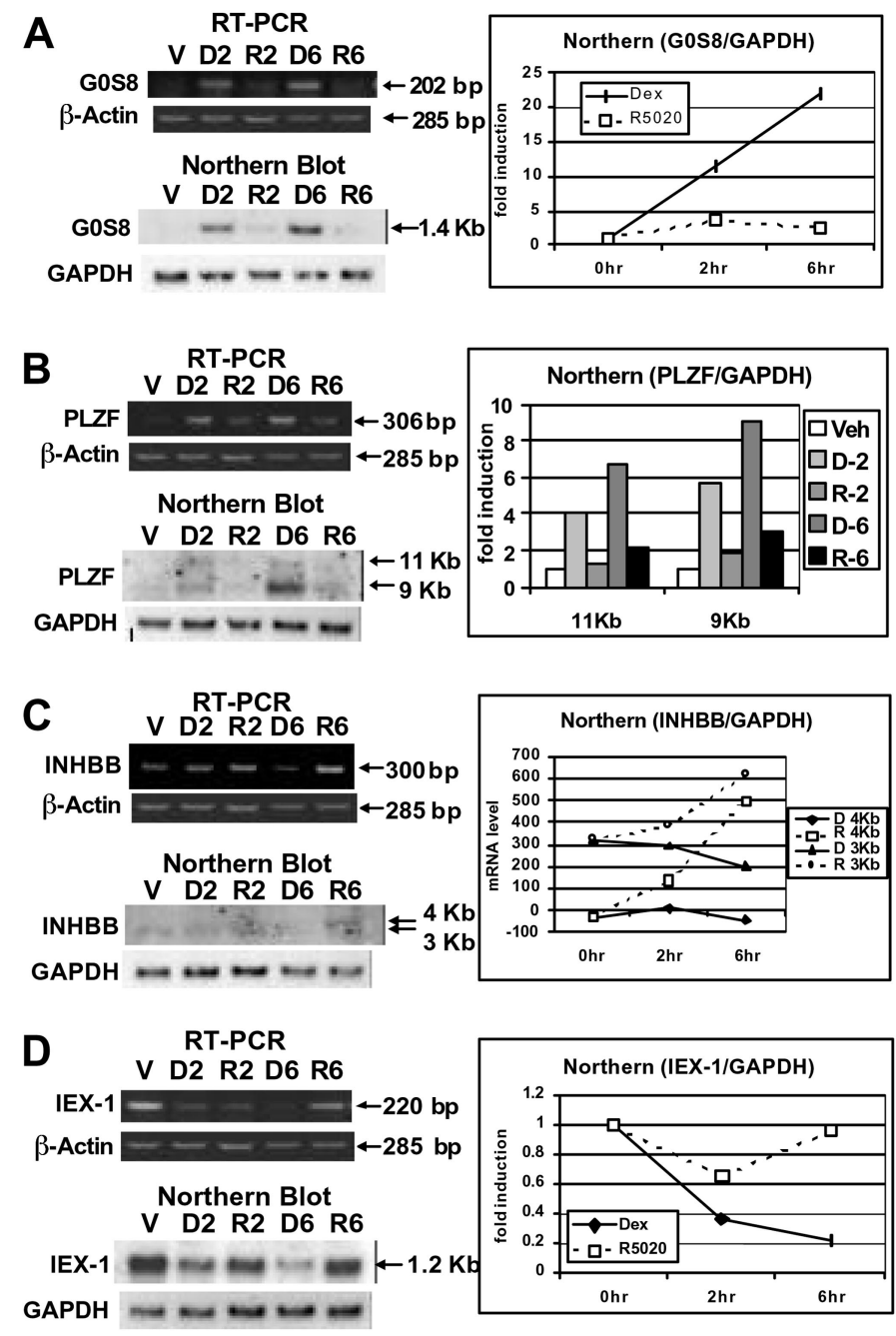

FIG. 2. Expression analyses of selected differentially regulated genes. T47D/A1-2 cells were treated with vehicle (V or Veh), dexamethasone (D, $100 \mathrm{nM})$, or R5020 (R, $10 \mathrm{nM})$ for 2 hours (D2 or R2) or 6 hours (D6 or R6). Total RNA was isolated and used for semiquantitative reverse transcription-polymerase chain reaction (RT-PCR) and Northern blot analyses. Quantitation of the Northern blot is shown on the right in each panel. (A) G0S8, a gene specifically induced by glucocorticoids. (B) Promyelocytic leukemia zinc finger (PLZF), a gene preferentially induced by glucocorticoids. (C) INHBB ( $\beta$ B subunit of inhibins and activins), a gene specifically induced by progestins. (D) IEX-1, a gene preferentially downregulated by glucocorticoids. [Reprinted with permission from Wan Y, Nordeen SK 2002 Overlapping but distinct gene regulation profiles by glucocorticoids and progestins in human breast cancer cells. Mol Endocrinol 16:1204-1214. Copyright The Endocrine Society.] 
of an incorrect call on genes more weakly regulated. Particularly if one sets a cutoff in the range of 1.8- to 2-fold, it is necessary to perform multiple repeats with cRNAs derived from independent experiments (Richer et al., 2002).

The relatively short induction times for gene identification (i.e., 2 and 6 hours) were chosen to optimize for identification of primary, receptor-mediated regulatory events, rather than secondary induction events. To confirm that the differential regulation of the four genes was direct and mediated by the cognate receptors, T47D/A1-2 cells were treated with the protein synthesis inhibitor cycloheximide or the GR/PR antagonist mifepristone (RU486) along with Dex or R5020. Total RNA was isolated and the expression of each gene was determined by semiquantitative RT-PCR. Although cycloheximide itself can have an effect on mRNA levels, the hormone-regulation pattern is maintained following cycloheximide treatment for all four genes, indicating that the hormone regulation is a direct effect that does not require de novo protein synthesis. In contrast, the hormone regulation is completely abolished following RU486 treatment, indicating that hormonal regulation is mediated through GR and/or PR.

\section{DIFFERENTIAL GENE REGULATION BY GLUCOCORTICOIDS AND PROGESTINS MAY MEDIATE HORMONE-SPECIFIC EFFECTS}

Progestins are associated with the incidence and progression of breast cancer (Horwitz, 1992). Recent work suggests that progestins may prime mammary cells to respond to growth factors (Lange et al., 1999). In contrast, glucocorticoids are growth suppressive in mammary cancer cells (Lippman et al., 1976; Goya et al., 1993). From the examination of the differentially regulated genes identified, a pattern emerged that gives insight into the differential effects on cell proliferation of the two hormones (Figure 3).

A number of the genes that are preferentially induced by glucocorticoids or suppressed by progestins are growth suppressive (Figure 3A; Table III). G0S8/ RGS2 encodes a basic helix-loop-helix phosphoprotein (Siderovski et al., 1994) and specifically inhibits the function of $\mathrm{Gq} \alpha$ as a GTPase-activating protein (Heximer et al., 1997). Knockout mice show reduced T-cell proliferation and antiviral immunity, increased anxiety responses, and decreased male aggression (Oliveira-Dos-Santos et al., 2000). G0S8/RGS2 has been shown to be induced in growth-arrested cells and to promote adipocyte differentiation (Nishizuka et al., 2001). The induction of G0S8/RGS2 also may play a role in the growthsuppressive effect of glucocorticoids in mammary carcinoma cells.

PLZF originally was identified as the fusion partner of the retinoic acid receptor alpha $(\operatorname{RAR} \alpha)$ gene in a variant chromosomal translocation in acute promyelocytic leukemia (APL) (Chen et al., 1993). It is a transcription repressor with a kruppel-like zinc finger domain and a BTB/POZ domain (Chen et al., 1993; Dong et al., 1996). PLZF represses transcription by recruiting a histone 


$\begin{array}{llll}\text { A. } & \text { G0S8 } & \text { G } & \text { Gqa inhibitor, } \downarrow \text { growth, } \uparrow \text { differentiation } \\ \text { PLZF } & \text { G } \uparrow & \text { transcription repressor, } \downarrow \text { growth, } \uparrow \text { apoptosis } \\ \text { RAR } 1 & \text { P } \downarrow & \downarrow \text { growth, } \uparrow \text { apoptosis } \\ \text { VDUP1 } & \text { P } \downarrow & \text { tumor suppressor, } \downarrow \text { thioredoxin \& growth } \\ & & & \\ \text { B. } & \text { Mac-2 BP } & \text { P } \uparrow & \text { tumor antigen, } \uparrow \text { in breast cancer } \\ & \text { INHBB } & \text { P } \uparrow & \uparrow \text { mammary gland growth \& development } \\ \text { Pim-2 } & \text { P } \uparrow & \text { protooncogene, } \uparrow \text { lymphoid tumors with c-myc } \\ \text { NaGalase } & \text { G } \downarrow & \text { extracellular matrix-degradation, } \uparrow \text { in cancer } \\ \text { MKP-2 } & \text { G } \downarrow & \uparrow \text { by growth factors, } \uparrow \text { in } v \text {-jun or K-ras tumors } \\ \text { IEX-1 } & \text { G } \downarrow & \uparrow \text { by serum \& growth factors, } \downarrow \text { differentiation }\end{array}$

FIG. 3. Differential gene regulation by glucocorticoids and progestins may mediate hormonespecific effect on mammary cancer cell proliferation. (A) Genes that are preferentially induced by glucocorticoids $(\mathrm{G})$ or suppressed by progestins (P) are growth suppressive. (B) Genes that are preferentially induced by progestins or suppressed by glucocorticoids are potentially proliferation related. $\mathrm{RAR}=$ retinoic acid receptor, $\mathrm{VDUP}=$ vitamin $\mathrm{D} 3$ upregulated protein, $\mathrm{MKP}=\mathrm{MAP}$ kinase phosphatase, $\mathrm{NaGalase}=$ alpha-N-acetylgalactosaminidase .

deacetylase through the silencing mediator of retinoic acid and thyroid hormone receptor (SMRT)-mSin3-histone deacetylase (HDAC) co-repressor complex (David et al., 1998). PLZF has been shown to suppress the growth of myeloid cells by inducing G0/G1 arrest and apoptosis, partly through the binding and repression of the cyclin A2 promoter (Shaknovich et al., 1998; Yeyati et al., 1999).

Growth-suppressive genes are also targets of progestin regulation. Of note are genes preferentially suppressed by R5020, including RAR gamma 1 $($ RAR $\gamma 1)$ and vitamin D3 upregulated protein 1 (VDUP1). RAR $\gamma$ inhibits proliferation and activates apoptosis in breast cancer cells (Fanjul et al., 1996; Raffo et al., 2000). VDUP1 suppresses cell proliferation by inhibiting the reducing potential of the disulfide-reducing protein thioredoxin and by downregulating thioredoxin expression (Nakamura et al., 1992,1997; Nishiyama et al., 1999). Expression of VDUP1 is downregulated in chemically induced rat mammary tumors (Yang et al., 1998). Thus, in mammary cancer cells, the growth-suppressive effect of glucocorticoids may be mediated through the induction of G0S8/RGS2 and PLZF, while the growth-promoting effect of progestins may be mediated through the downregulation of RAR $\gamma$ and VDUP1. 
In contrast, many of the genes that are preferentially induced by progestins or suppressed by glucocorticoids are potentially proliferation related (Figure 3B; Table III). INHBB is induced by progestins but not glucocorticoids (Table III). Inhibins and activins are members of the transforming growth factor beta (TGF $\beta$ ) superfamily, which are potent mediators of proliferation or antiproliferation and differentiation in different cell types. A suggestion that INHBB is involved in growth regulation in the mammary gland comes from studies in which female mice deleted for both alleles of INHBB have lactation failure due to retarded ductal elongation and alveolar morphogenesis during puberty, pregnancy, and parturition (Robinson and Hennighausen, 1997). Other preferentially progesterone-induced genes include Pim-2, a proto-oncogene that induces lymphoid tumors synergistically with c-myc in mice (Allen et al., 1997; Baytel et al., 1998), and Mac-2 binding protein/90K, a tumor-derived antigen expressed at elevated levels in the serum of patients with breast and other types of cancer (Fusco et al., 1998).

IEX/Dif-2 represents but one of several genes whose downregulation by glucocorticoids may contribute to the inhibition of growth or tumorigenesis. IEX-1 was identified as a radiation-inducible, immediate-early gene in human squamous carcinoma cells (Kondratyev et al., 1996). Also known as Dif-2, it is downregulated during monocyte differentiation (Pietzsch et al., 1997). The IEX-1/Dif-2 gene is induced by multiple signals, many of which are associated with proliferation (e.g., lipopolysaccharide, $\mathrm{C}_{2}$-ceramide, lysophosphatidylcholine, phorbol esters, serum, growth factors) (Pietzsch et al., 1997; Schafer et al., 1999). The association of IEX-1/Dif-2 with proliferation suggests that the growth-suppressive effect of glucocorticoids in mammary carcinoma cells is mediated, in part, through the downregulation of IEX-1/Dif-2.

Other dexamethasone-downregulated genes include MAP kinase phosphatase (MKP-2) and alpha-N-acetylgalactosaminidase (NaGalase). MKP-2 can be induced by growth factors and is upregulated in cells transformed by v-Jun or mutated K-ras (Fu et al., 2000; Yip-Schneider et al., 2001). NaGalase is an extracellular matrix-degrading enzyme that is produced exclusively by cancer cells (Yamamoto et al., 1996). NaGalase levels in mice bearing squamous cell carcinoma increased with time of tumor growth and were directly proportional to tumor burden (Korbelik et al., 1998). Thus, in mammary cancer cells, growthsuppressive effect of glucocorticoids may be mediated through the downregulation of NaGalase, MKP-2, and IEX-1/Dif-2, while growth-promoting effect of progestins may be mediated through the induction of Mac-2 BP/90K, INHBB, and Pim-2.

In addition to the effects on mammary cancer cell growth, glucocorticoids promote milk protein synthesis and lactation (Doppler et al., 1989; Groner et al., 1994; Groner and Gouilleux, 1995), while progestins inhibit milk production and secretion (Graham and Clarke, 1997). Vasoactive intestinal polypeptide (VIP) 
receptor-related protein is the long isoform of VIP receptor. VIP has been shown to be a physiological mediator of prolactin release in the rat (Abe et al., 1985). Our data suggest that glucocorticoid-specific stimulation of lactation may be, in part, mediated by glucocorticoid-specific induction of VIP receptors (Table III).

To test the implications of the array data, along with the suggestions of other studies indicating that glucocorticoids and progestins have different effects on the proliferation of the mammary gland and mammary cancer cells, we investigated the effects of hormones on T47D/A1-2 cells. We assessed cell growth by monitoring the total DNA content of hormone-treated cell populations (Figure 4A). The results demonstrated that Dex treatment inhibited cell growth throughout the time course, while R5020 treatment initially stimulated cell growth and then became inhibitory. To examine further the effect of glucocorticoids and progestins on the cell-cycle progression of T47D/A1-2 cells within the first 24 to 48 hours after hormone treatment, we also assessed cell cycle by flow cytometry (Figure 4B). Typical of a nonsynchronous population of proliferating cells, approximately $30 \%$ of untreated cells are in S or G2/M phases. Dex treatment decreased the fraction of cells in $\mathrm{S}+\mathrm{G} 2 / \mathrm{M}$ throughout the time course. By 48 hours, the fraction of cells in $\mathrm{S}+\mathrm{G} 2 / \mathrm{M}$ had declined from $30 \%$ to $13 \%$,
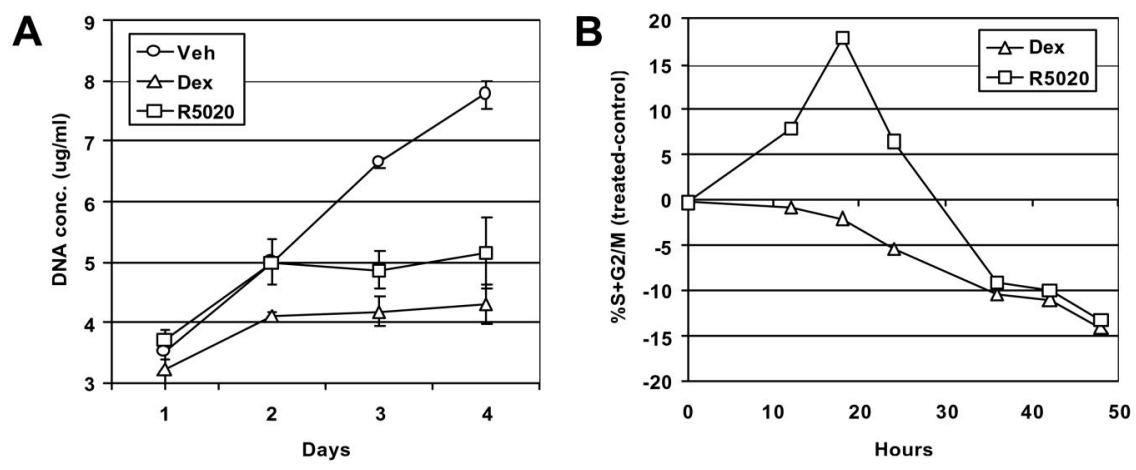

FIG. 4. Glucocorticoids and progestins mediate different effects on the growth of T47D/A1-2 cells. (A) T47D/A1-2 cells were treated with vehicle, Dex (100 nM), or R5020 (10 nM) for the indicated number of days. Cell proliferation was determined by measuring DNA content in each well using Hoechst DNA assay. The experiment shown is representative of three independent experiments, each done in triplicate \pm standard error (SE). (B) T47D/A1-2 cells were treated with vehicle, Dex $(100 \mathrm{nM})$, or R5020 (10 nM) for the indicated number of hours. The fraction of cells in S+G2/M was measured by flow cytometry. The ordinate indicates the difference between the fraction of cells in $\mathrm{S}+\mathrm{G} 2 / \mathrm{M}$ in the hormone-treated sets and the fraction of cells in $\mathrm{S}+\mathrm{G} 2 / \mathrm{M}$ in the vehicle-treated controls. In this study, approximately $25-35 \%$ of control cells were in S+G2/M. [Reprinted with permission from Wan Y, Nordeen SK 2002 Overlapping but distinct gene regulation profiles by glucocorticoids and progestins in human breast cancer cells. Mol Endocrinol 16:1204-1214. Copyright The Endocrine Society.] 
suggesting that Dex treatment led to a cell-cycle arrest in G1. This supports the observation in a previous study that Dex suppresses the growth of Con8 rat mammary tumor cells by inducing a G1/G0 cell-cycle arrest (Goya et al., 1993). In contrast, R5020 treatment initially increased the fraction of cells in S+G2/M. At the peak (i.e., around 18 hours), almost half of the cell population was in $\mathrm{S}+\mathrm{G} 2 / \mathrm{M}$, a $63 \%$ increase over control. Together with the initial increase in DNA content, this indicates that progestins initially are growth promoting. By 30-36 hours after R5020 treatment, the fraction of cells in S+G2/M dropped below controls, to a level similar to Dex-treated cells, indicating that after the initial stimulation, progestins mediate a growth-suppressive action. This biphasic effect of progestins on the cell-cycle progression of T47D cells has been previously described (Musgrove et al., 1991; Groshong et al., 1997). It has been proposed that progestin treatment initially drives cells to go through the first cell cycle to a decision point at the G1/S boundary. Secondly, it induces cellular changes that permit other factors to influence the ultimate proliferative or differentiative state of the cells (Lange et al., 1999). For example, only progestin-primed T47D cells become highly sensitive to the proliferative effects of epidermal growth factor (EGF) (Groshong et al., 1997). Together, the T47D/A1-2 cell growth and cell-cycle studies clearly demonstrated that, during the first 24 hours of hormone treatment, glucocorticoids are growth suppressive, while progestins are growth stimulating. The early time points (i.e., 2 hours and 6 hours) used in our microarray analysis permitted the identification of candidate genes that may mediate the differential growth effects of the two hormones on T47D/A1-2 cells.

In summary, the genes identified to be differentially regulated by glucocorticoids and progestins provide potential mechanisms through which the two hormones exert different or opposite biological effects. With a better understanding of the functionally uncharacterized genes identified here, more potential mechanisms will emerge. Future studies exploring these mechanisms will assist in developing tumor markers and therapeutic agents for cancer. In addition, genes identified in this study can be used as model systems to investigate the molecular mechanisms underlying differential gene regulation by glucocorticoids and progestins. Our preliminary studies have mapped the glucocorticoid-mediated inhibition of tumor necrosis factor alpha (TNF $\alpha$ )-induced IEX-1/Dif-2 promoter activity to a small proximal promoter region containing an nuclear factor kappa beta $(\mathrm{NF}-\kappa \beta)$ element and juxtaposed SP-1-CCAT/enhancer binding protein (C/EBP) elements (Y. Wan, unpublished data). The mutually inhibitory actions of GR and NF- $\kappa \beta$ have been well documented (McKay and Cidlowski, 1999). The fruits of these investigations will enhance our appreciation of the larger question of how related transcription factors mediate distinct, even opposing, biological actions. 


\section{Cre/loxP-mediated Retroviral Promoter-trapping System}

\section{A. ESTABLISHMENT OF A CRE/LOXP-MEDIATED RETROVIRAL PROMOTER-TRAPPING SYSTEM}

While microarray analysis is of unquestioned utility in many approaches to the study of hormonal regulation, like any methodology, it has specific shortcomings. For example, detection of genes expressed at low levels can be a problem. Also, hormone inductions that are transient or that induce apoptosis can present technical challenges. To address these difficulties and to identify promoters differentially induced by glucocorticoids and progestins, we have adapted a novel retroviral promoter-trapping system developed by von Melchner and colleagues (Russ et al., 1996).

To generate a cell line that expresses both GR and PR, we stably introduced a PR-B expression vector into a glucocorticoid-responsive $\mathrm{Ltk}^{-}$fibroblast cell line (Thackray et al., 1998). The resulting cell line, 4F, is responsive to both glucocorticoids and progestins, although PR is at least 10-fold more abundant than GR in each 4F cell (Thackray et al., 1998). A multifunctional reporter plasmid was introduced into the $4 \mathrm{~F}$ cells whose purpose was the sensitive detection of Cre recombinase expression (Figure 5). The ppgklxtkneo/hygro reporter plasmid consists of two, tandemly arrayed selective marker genes that are transcribed from a $p g k$ promoter. The $5^{\prime}$-selective marker gene encodes for a fusion protein between herpes simplex virus 2 thymidine kinase $(t k)$ and the neomycin phosphotransferase (neo) and is flanked by two direct repeats of the loxP-recombination target site (Bartsch et al., 1996). The 3 '-selective marker

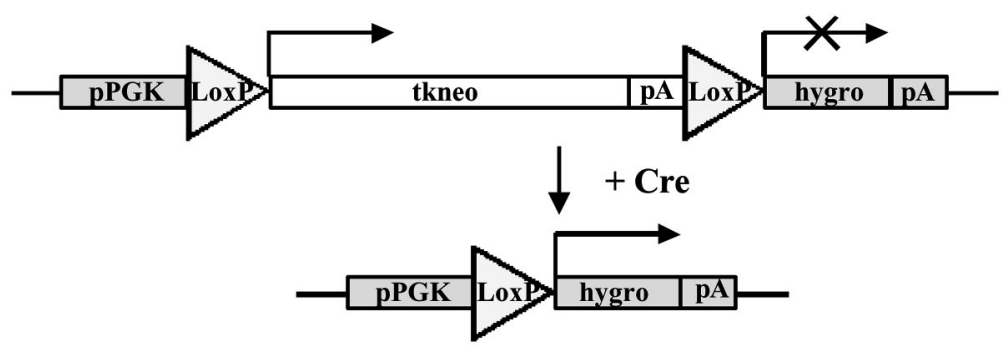

FIG. 5. Schematic of the multifunctional selection plasmid (ppgklxtkneo/hygro) before and after Cre-mediated recombination at loxP sites. Functional components are labeled as follows: pPGK, mouse phosphoglycerate kinase promoter; tkneo, herpes simplex virus 2 thymidine kinase $(t k)$ neomycin phosphotransferase (neo) fusion gene; hygro, hygromycin-B phosphotransferase; pA, a pair of polyadenylation signals from the growth hormone gene; lox $P$, Cre recombination target sequences. [Reproduced by permission of the Society of Endocrinology from Wan Y, Nordeen SK 2002 Identification of genes differentially regulated by glucocorticoids and progestins using a Cre/loxP mediated retroviral promoter-trapping strategy. J Mol Endocrinol 28:177-192.] 
gene encodes for hygromycin phosphotransferase (hygro) and is located downstream of the second loxP site. In the absence of Cre, the tkneo gene is expressed from the constitutive $p g k$ promoter. The hygro gene does not have a promoter immediately upstream and chimeric transcripts initiated at the $p g k$ promoter are suppressed by two tandem copies of the bovine growth hormone polyadenylation sequence upstream of hygro. Therefore, the cells containing a single copy of ppgklxtkneo/hygro are G418 resistant but hygromycin sensitive. However, when Cre is expressed, it will catalyze recombination between the two loxP sites, resulting in the deletion of tkneo. This places hygro immediately downstream of the $p g k$ promoter, rendering the cells G418 sensitive but hygromycin resistant (Figure 5). Thus, 4F cells with a stably integrated ppgklxtkneo/hygro selection plasmid report even transient expression of Cre by undergoing a permanent switch in their drug-resistance phenotype.

A G418-resistant clone containing a single copy of the selection plasmid was selected for further analysis. First, we determined whether the G418-resistant clone was sensitive to hygromycin by placing $5 \times 10^{5}$ cells under hygromycin $(500 \mu \mathrm{g} / \mathrm{ml})$ selection. Because no colony formed within 12 days, we concluded that neither leaky hygro translation nor spontaneous recombination occurred in these cells at levels that would interfere. Second, we determined whether the $4 \mathrm{~F}$ clone with a single integrated copy of the selection plasmid would become hygromycin resistant and neomycin sensitive after Cre expression. An expression plasmid (pCMVCre) was transiently transfected into the cells by a calcium phosphate coprecipitation method. Cells were selected for hygromycin (500 $\mu \mathrm{g} / \mathrm{ml}$ ) resistance. The hygromycin-resistant cells were pooled and placed under G418 $(1 \mathrm{mg} / \mathrm{ml})$ selection for 12 days to test neomycin sensitivity. Because all the hygromycin-resistant cells were neomycin sensitive, we concluded that the cells could undergo a clean, drug-resistance phenotype switch after Cre expression. Thus, Cre expression, even transiently, results in a permanent phenotypic change that can be selected.

In order to utilize this property to trap cellular promoters, we employed a self-inactivating retroviral gene-trap vector (U3Cre) (Russ et al., 1996) to deliver a promoterless Cre gene to the $4 \mathrm{~F}$ target cells with the integrated selection plasmid. The U3Cre plasmid was stably transfected into an amphitropic packaging cell line, PA317 (Miller and Buttimore, 1986). Supernatants from lines producing high titers of recombinant virus were used to infect $4 \mathrm{~F}$ target cells with a single copy of the ppgklxtkneo/hygro selection plasmid, resulting in a library consisting of approximately $4 \times 10^{6}$ independent proviral integration events. The structure of the U3Cre vector, when it is integrated in a proviral form, is shown in Figure 6. Cre coding sequences are positioned near the $5^{\prime}$ end of the U3 region of an enhancer-deleted long terminal repeat (LTR). Viral replication and LTRmediated duplication place the Cre coding sequence in the $5^{\prime}$ LTR, just 30 nucleotides from the flanking cellular DNA (Figure 6) (von Melchner and Ruley, 


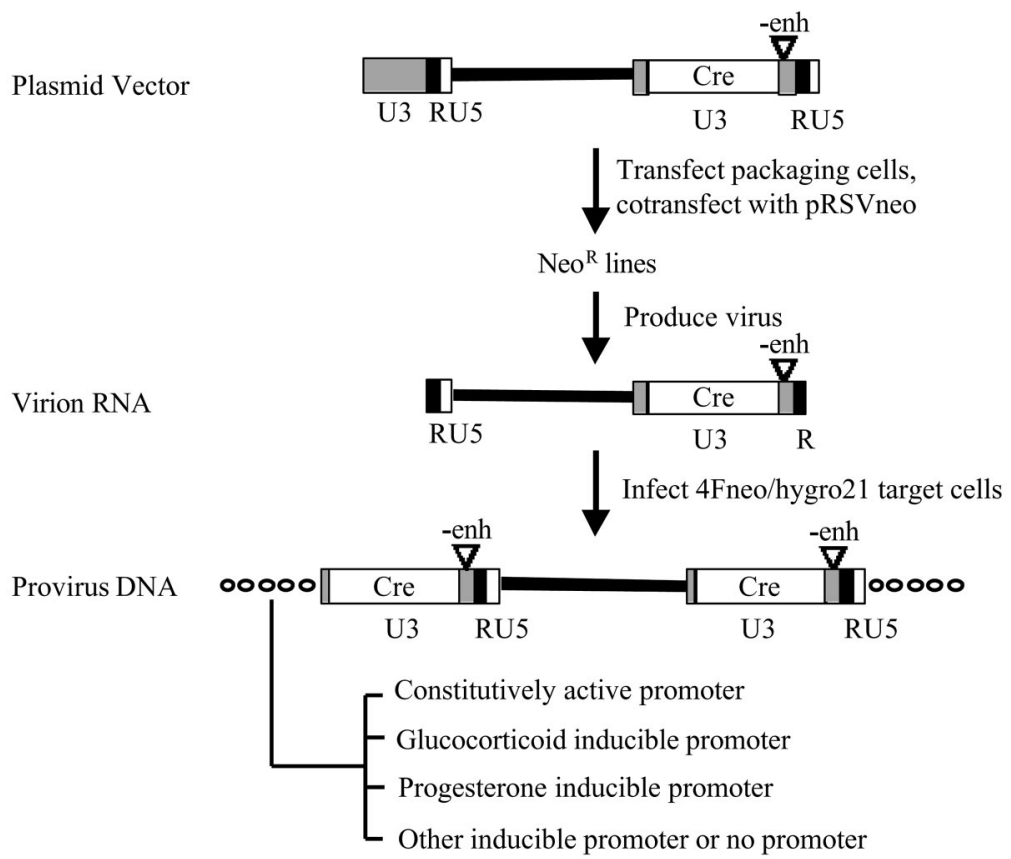

FIG. 6. Structure and replication of the U3Cre retroviral vector. Functional components are labeled as follows: Cre, modified bacterial phage P1 Cre recombinase; U3, R, and U5 are segments of the viral long terminal repeat (LTR). "-enh" indicates "enhancer deleted." Infection of 4Fneo/ hygro21 target cells generates provirus in which the 5' Cre coding sequence is immediately downstream of cellular sequence. $\mathrm{Neo}^{\mathrm{R}}$, G418 resistant. [Reproduced by permission of the Society of Endocrinology from Wan Y, Nordeen SK 2002 Identification of genes differentially regulated by glucocorticoids and progestins using a Cre/loxP mediated retroviral promoter-trapping strategy. J Mol Endocrinol 28:177-192.]

1989; von Melchner et al., 1990; Russ et al., 1996). Therefore, Cre is not expressed unless the virus integrates into an active cellular promoter.

A potential complication arises from the duplication of the Cre coding sequence in the $3^{\prime}$ LTR. In clonal cell lines with a stably integrated U3Cre provirus, there typically are two Cre transcripts: a cellular-proviral fusion transcript initiating from the upstream cellular promoter and terminating at the polyadenylation site of the 5' LTR, and a "viral genomic" transcript initiating from the $5^{\prime}$ proviral LTR and terminating at the polyadenylation site of the $3^{\prime}$ LTR (Russ et al., 1996). The double Cre transcripts can complicate the analysis of the selected cell lines, since the viral genomic transcript can obscure the Cre transcript from the cellular promoter. However, translation of Cre from the viral genomic transcript within the $3^{\prime}$ LTR is unlikely due to multiple, short, openreading frames positioned between the LTRs. Furthermore, several previous 
studies have shown that, in most cases, activation of the promoter-trap is associated with the translation of Cre from the cellular-proviral fusion transcripts (von Melchner and Ruley, 1989; von Melchner et al., 1990; Reddy et al., 1991; Chang et al., 1993; Russ et al., 1996). Therefore, the 3' copy of Cre doesn't contribute to Cre protein expression and interfere with the assessment of promoter trapping. In this work, we employ Cre expression coupled to drug selection phenotypes to identify hormone-regulated promoters.

\section{B. ISOLATION OF CELL LINES REPRESENTING TRAPPED, HORMONE-INDUCIBLE, AND DIFFERENTIALLY HORMONE-INDUCIBLE PROMOTERS}

Clonal cell lines were isolated following sequential drug selections, as outlined in Figure 7. Clones in which U3Cre had integrated near constitutive promoters, resulting in constitutive Cre expression, were eliminated because Cre-mediated recombination eliminates the neomycin phosphotransferase gene. This renders these cells sensitive to continued selection in G418. The selection scheme diagrammed for cell clones of group A enriches for promoters induced by progestins, whereas group B is enriched for promoters induced by glucocorticoids. Trapped promoters preferentially induced by glucocorticoids vs. progestins are enriched in cell clones of group C; conversely, promoters preferentially induced by progestins are trapped in the scheme giving group D cell clones. Forty cell lines from each of group A and group B, and an additional 20 cell lines from each of group $\mathrm{C}$ and group $\mathrm{D}$, were isolated for further analysis.

To determine the expression pattern of the gene represented in each clonal cell line isolated, we developed a reporter assay to quantitate the Cre protein level, based on Cre recombinase activity (Figure 8). A reporter plasmid (ppgklxtkneo/luc) (Figure 8A) was constructed in which the hygro gene of the multifunctional selection plasmid was replaced by luciferase $(l u c)$. Luciferase expression from this plasmid was dependent on Cre expression. A titration of Cre expression vector demonstrated that the higher the input of Cre, the higher the output of luciferase expression (Figure $8 \mathrm{~B})$. Therefore, this sensitive and quantitative luciferase reporter strategy can determine the exact regulation pattern of the trapped promoters in each isolated cell clone and allow the identification of the lines that represent genes that are differentially regulated by the two hormones.

Each clonal cell line with potentially hormone-regulated, trapped promoters was transfected with ppgklxtkneo/luc and treated with Dex or R5020 24 hours later. The induction of Cre activity was assessed by the deletion of sequences flanked by loxP sites, as measured by the appearance of luciferase activity. In 58 cell lines, luciferase expression was induced by either glucocorticoids or progestins by more than 2-fold. In 19 cell lines, luciferase expression was differentially regulated by the two hormones by more than 1.5 -fold (Figure $8 \mathrm{C}$ ). 


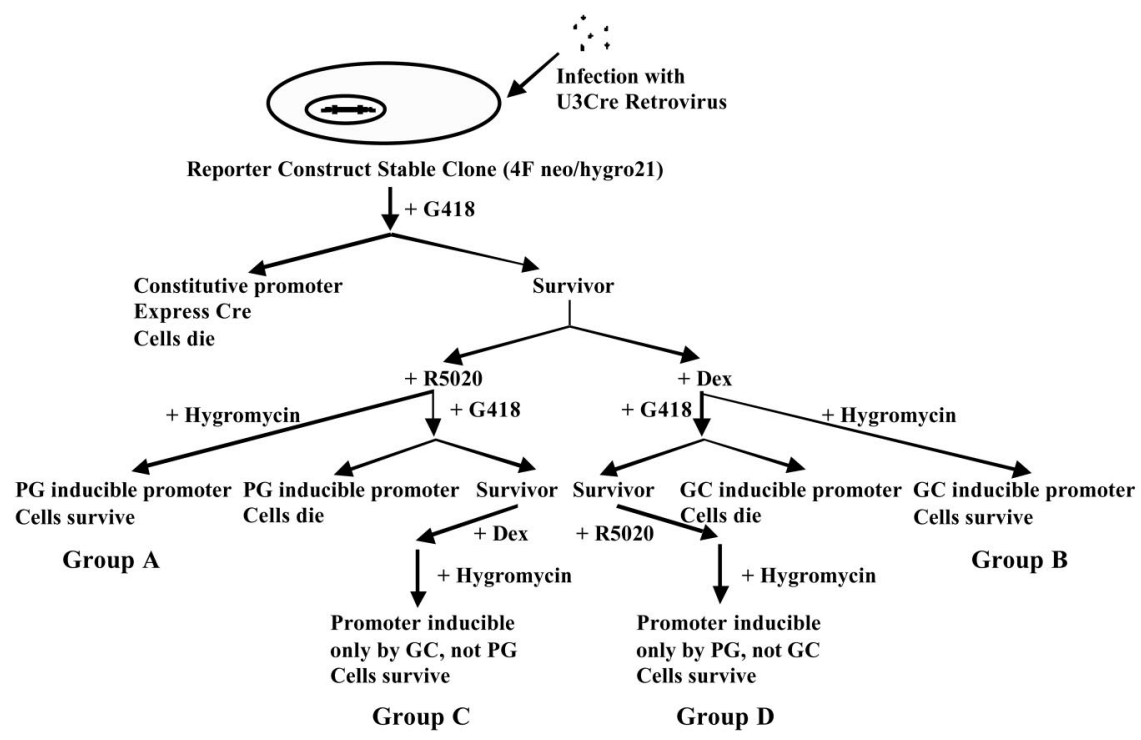

FIG. 7. Schematic illustration of the sequential selection procedure to identify $4 \mathrm{~F}$ cell lines representing a trapped promoter that is induced or differentially induced by glucocorticoids and progestins. Retrovirus-transduced cells were placed first under G418 (1 mg/ml) selection for 5 days. Those cells in which the Cre gene is integrated downstream of a constitutively active cellular promoter will be eliminated due to the expression of Cre and thus the deletion of the tkneo gene. The survivors were split into two groups in media without G418. One group was treated with R5020 (10 $\mathrm{nM})$ and the other with Dex $(100 \mathrm{nM})$ for 24 hours. The cells then were subjected to hygromycin (500 $\mu \mathrm{g} / \mathrm{ml}$ ) selection, to select for cells in which Cre expression has been induced by hormone. Thus, this selection will enrich for cells in which the Cre gene was integrated downstream of a progestininducible promoter (group A) or a glucocorticoid-inducible promoter (group B). To maximize the identification of genes preferentially induced by one of the two hormones, an additional step was added to the selection scheme. After the initial G418 selection to eliminate constitutively expressed promoters, another selection was added to eliminate promoters induced by progestins (group C) or glucocorticoids (group D). This was done by adding the appropriate hormone for 24 hours and continuing G418 selection for 5 days. Survivors in the progestin-treated group C were removed from G418 and treated with Dex for 24 hours. Similarly, the glucocorticoid-treated group D was removed from G418 and treated with R5020 for 24 hours. The two groups were then placed under hygromycin selection to enrich for cells expressing Cre under the control of the appropriate hormone. GC, glucocorticoids; PG, progestins; Dex, dexamethasone, a synthetic glucocorticoid; R5020; a synthetic progestin. [Reproduced by permission of the Society of Endocrinology from Wan Y, Nordeen SK 2002 Identification of genes differentially regulated by glucocorticoids and progestins using a Cre/loxP mediated retroviral promoter-trapping strategy. J Mol Endocrinol 28:177-192.]

\section{HORMONE REGULATION OF SELECTED PROMOTERS}

In order to determine whether the endogenous cellular genes trapped in the clonal cell lines are, indeed, hormone regulated, genomic DNA sequences 

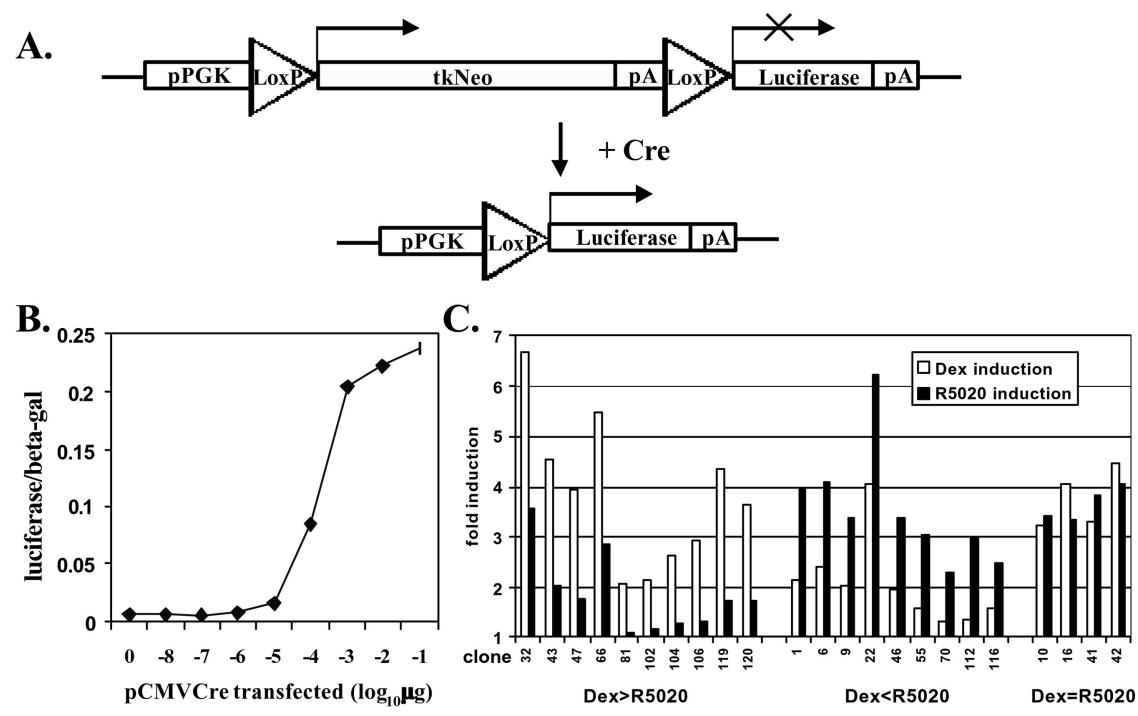

FIG. 8. Quantitation of Cre protein expression in clonal cell lines by transfection of ppgklxtkneo/luc. (A) Schematic of ppgklxtkneo/luc reporter construct before and after Cre-mediated recombination at $\operatorname{lox} P$ sites. Gene sequences are labeled as in Figure 5. (B) A dose curve demonstrating that relative levels of Cre activity can be analyzed by recombination of ppgklxtkneo/ luc and concomitant production of luciferase activity. Increasing amounts of the expression plasmid pCMVCre were transiently transfected into the 4Fneo/hygro21 cell line. A constant amount of the reporter tkneo/luc $(1 \mu \mathrm{g} / \mathrm{ml})$ and an internal control plasmid pCMV $\beta$-gal $(0.1 \mu \mathrm{g} / \mathrm{ml})$ were cotransfected. Cells were harvested 72 hours later. The result was shown as luciferase activity normalized to $\beta$-galactosidase (gal) activity. (C) Identification of clonal cell lines that represent promoters differentially regulated by glucocorticoids and progestins by quantitating Cre protein expression. The reporter plasmid ppgklxtkneo/luc $(1 \mu \mathrm{g} / \mathrm{ml})$ was transiently transfected into each clonal cell line with an internal control plasmid pCMV $\beta$-gal $(0.1 \mu \mathrm{g} / \mathrm{ml})$. After $20-24$ hours, cells were treated with vehicle, Dex $(100 \mathrm{nM})$, or R5020 $(10 \mathrm{nM})$. Cells were harvested 48 hours after treatment. The results were illustrated as the fold of induction of the luciferase activity, normalized to $\beta$-galactosidase activity. Shown are 19 cell lines that represent promoters differentially regulated by the two hormones by more than 1.5 -fold: Dex $>$ R5020 indicates that the promoters are preferentially induced by Dex; Dex $<$ R5020 indicates that the promoters are preferentially induced by R5020. In addition, four examples of the cell lines that represent promoters induced by both hormones by more than 2-fold are shown $($ Dex $=$ R5020). [Reproduced by permission of the Society of Endocrinology from Wan Y, Nordeen SK 2002 Identification of genes differentially regulated by glucocorticoids and progestins using a Cre/loxP mediated retroviral promoter-trapping strategy. J Mol Endocrinol 28:177-192.]

upstream of the proviral integration site of several clonal isolates were retrieved by inverse PCR and sequenced. Recovered sequences ranged from 154 to $874 \mathrm{bp}$. Blast searches using different databases revealed that the 441-bp sequence upstream of the proviral integration site in clone 43 is $98 \%$ identical with the expressed sequence tag (EST) ic84f11.x1 in the cDNA library "Melton Normal- 
ized Mixed Mouse Pancreas 1 N1-MMS1” (dbEST ID 9280663, GenBank accession number BI438077). However, the sequences upstream of the proviral integration sites in clone 32, 42, and 66 showed no significant homology to known genes or ESTs at the time of analysis. This was not unexpected, since this trapping system is very sensitive to even low levels of Cre expression, so even promoters with weak basal expression are eliminated in the initial selection. Because of their very low expression, identification of these transcription units might be easily missed by conventional gene-discovery approaches. Another reason that cDNAs for these transcription units may not be found in the databases stems from the design of the U3Cre retroviral construct that selects for integration sites in 5' nontranslated regions (von Melchner et al., 1990; see Wan and Nordeen, 2002a, for discussion). The $5^{\prime}$-most part of the transcription unit is most likely to be absent from all but full-length cDNA clones in the databases. The sequences of the novel transcripts have been deposited in GenBank; accession numbers are AF465703 (for clone 32 gene), AF465704 (for clone 42 gene), and AF465705 (for clone 66 gene).

Three of the four proximal flanking sequences (clone 32, 42, and 43) were able to be amplified by RT-PCR from the RNA isolated from the parental cell line (4F), suggesting that the upstream sequences are within an exon of the gene. The primers designed for the upstream sequences of clone 66 did not give RT-PCR product, even though they can amplify the genomic DNA. The integration site in this clone may not be in exonic sequence or, more likely, the 5' primer is upstream of the transcription start site.

The mRNA level of the gene represented by clone 32 (clone 32 gene) in the parental cell line (4F) was measured by semiquantitative RT-PCR. Serially diluted cDNAs were amplified by PCR to select the cycle number that gave the best linear relationship between the cDNA input (x value) and the PCR output (y value) for each specific primer set (Figures 9A and B). Then, the cDNAs in each hormone-treated sample were amplified at this cycle number, with the linear standard run at the same time. The PCR output in each sample was quantitated and the amount of cDNA input was calculated using the linear relationship derived from the standard (Figure 9C). The result demonstrated that clone 32 gene was preferentially induced by glucocorticoids (5-fold), compared to progestins (2.5-fold). Although this is only a 2-fold difference in induction, it is more impressive when one considers that progesterone receptors are 10-fold more abundant than glucocorticoid receptors in these cells. Expression of the genes represented by the other two clones was quantitated in the same way. Clone 43 gene also was preferentially induced by glucocorticoids. Glucocorticoids induced gene 43 by two-fold, while progestins gave no induction or a slight inhibition. Clone 42 gene was induced by both hormones to a similar level. For all three clones, the mRNA-regulation patterns of the endogenous genes agree 
A.

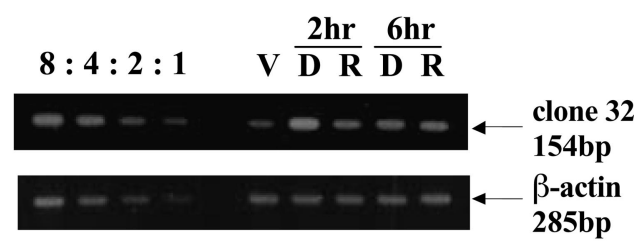

B.

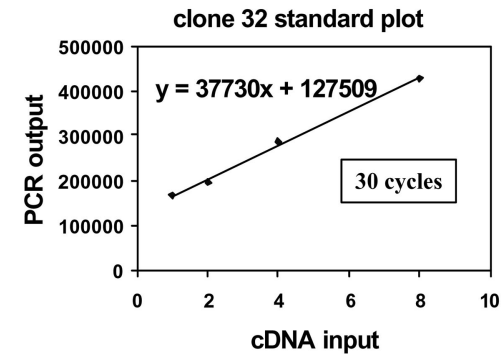

C.

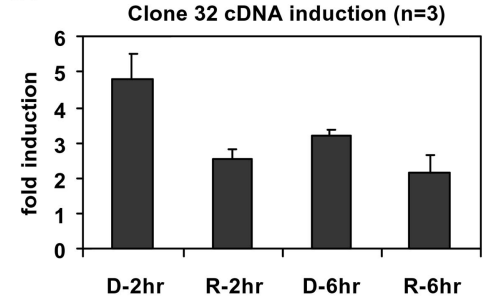

FIG. 9. Quantitation of the mRNA level of clone 32 gene in $4 \mathrm{~F}$ cells by semiquantitative RT-PCR. (A) Parental cells (4F) were treated with vehicle (V), dexamethasone (D, $100 \mathrm{nM}$ ), or R5020 (R, $10 \mathrm{nM}$ ) for 2 hours or 6 hours. Total RNA was isolated and used for semiquantitative RT-PCR. The left four lanes show the standard. (B) The linear relationship between the cDNA input and the PCR output for clone 32 gene (left) and the $\beta$-actin control (right) at the indicated PCR cycle. (C) Quantitation of clone 32 gene-specific cDNA normalized by $\beta$-actin-specific cDNA in each hormone-treated sample. The result was shown as fold of induction, compared to vehicle-treated sample. The figure depicts the results of three independent experiments. Bars represent $\pm \mathrm{SE}$. [Reproduced by permission of the Society of Endocrinology from Wan Y, Nordeen SK 2002 Identification of genes differentially regulated by glucocorticoids and progestins using a Cre/loxP mediated retroviral promoter-trapping strategy. J Mol Endocrinol 28:177-192.]

with the Cre protein-regulation patterns shown in Figure 8C, suggesting that the genes identified using this strategy are, indeed, regulated by hormones.

For two clones (32 and 43), we further examined the expression of the cellular-Cre fusion transcript to ascertain whether it is regulated by hormones in the same fashion as the endogenous gene. Clonal cell lines 32 and 43 were treated with hormone for 2 hours and total RNA was isolated. Semiquantitative RT-PCR analyses were performed with a $5^{\prime}$ primer from the endogenous gene and a $3^{\prime}$ primer from Cre sequence. A PCR product of the predicted size was amplified from cDNA. Furthermore, both fusion transcripts were preferentially induced by glucocorticoids compared to progestins, as was observed for the endogenous genes.

The hormone regulation of clone 32 gene was examined further to ascertain whether the induction is a direct hormone effect and whether the differential 
induction is mediated by the appropriate receptor. Treatment with the protein synthesis inhibitor cycloheximide did not abolish hormone induction, suggesting that the regulation is a direct event independent of de novo protein synthesis. Treatment with the GR/PR antagonist RU486 blocked the glucocorticoid induction but ZK112993, which preferentially blocks progesterone receptor at the dose used, did not, demonstrating that the induction of clone 32 gene by glucocorticoid is mediated by GR. The glucocorticoid induction of the clone 32 gene peaked by 30 minutes, again indicating that this is a direct response. The hormone induction lasted for at least 22 hours. Assessment of the hormone regulation of clone 32 gene in two other cell lines indicated that the glucocorticoid induction of clone 32 gene is cell-type specific. Clone 32 gene is induced by glucocorticoid in mouse fibroblast cell lines (L929 and 4F) but not the GR-expressing human breast cancer cell line T47D/A1-2. In summary, the Cre/loxP-mediated retroviral promoter-trapping system described here has successfully identified novel genes that are differentially induced by glucocorticoids and progestins.

\section{Summary}

In this review, we describe two different strategies that we have employed to identify genes that are differentially regulated by glucocorticoids and progestins. The first strategy, Affymetrix microarray analysis, is a high-throughput approach that allows quick examination of the expression of thousands of known genes at the same time. The design of the Affymetrix oligoarrays and the supporting statistical analysis algorithm permit the accurate determination of the relative level of each mRNA species. This global analysis reveals that glucocorticoids and progestins regulate overlapping, but distinct, sets of genes, including 31 genes that are differentially regulated. Surprisingly, the set of differentially regulated genes was almost as large as the set of genes regulated by both hormones. Examination of the set of differentially regulated genes suggests mechanisms behind the distinct growth effects of the two hormones in breast cancer.

The second strategy combines a retrovirally delivered promoter trap and Cre/loxP-mediated, site-specific recombination to identify differentially hormoneregulated genes. This strategy has several advantages, compared to microarray analysis. It is proficient at the detection of transiently hormone-activated promoters. Since the Cre-mediated recombination at $\operatorname{lox} P$ sites is an irreversible event, even transiently activated promoters can produce enough Cre recombinase to create a permanent switch of drug-resistance phenotype. Thus, screening can be accomplished even when a brief induction period is used to avoid cytotoxicity or induction of apoptosis that might result from a longer treatment (Russ et al., 1996). In addition, the promoter trap is not biased toward highly expressed genes. Little Cre expression 
is required to catalyze recombination at the loxP sites. Therefore, unlike many conventional strategies (e.g., cDNA library screening, RNA differential display, microarray analysis), this Cre/lox selection strategy can detect weakly expressed genes. The promoter trap allows discovery of unknown genes. Finally, it allows a near-saturation screening of the whole genome. If we infect the target cell line with the U3Cre retrovirus at a multiplicity of infection (MOI) of 0.5 to ensure single integration events and perform selections on $10^{7}$ integrants, this will yield one integration per 300 base pairs, assuming random integration. Nonetheless, the advantage of the exquisite sensitivity of this system also can be a drawback. Because the selection against any basal expression is strong, regulated promoters exhibiting some basal level of expression will be missed. Future application of this system might benefit from damping the sensitivity through the use of a less-active Cre or suboptimal loxP sites. This might permit some level of Cre expression without promoting recombination of the selection vector sequences. Using this system, a group of 19 clonal cell lines representing genes differentially regulated by glucocorticoids and progestins have been isolated. Two novel genes (clone 32 and 43 genes) have been confirmed to be preferentially induced by glucocorticoids, compared to progestins

Despite the disparate biological activities of the two receptors, there is little information on what genes may be differentially regulated by the two receptors and how this may be accomplished. Our studies document novel approaches toward addressing this void. Further studies of the mechanisms underlying the differential regulation will enhance our understanding of how glucocorticoids and progestins function as specific physiological regulators or therapeutic agents.

\section{ACKNOWLEDGMENT}

This work has been supported by grant award DK37061 from the National Institutes of Health to S.K.N. and predoctoral fellowship award DAMD17-99-1-9445 from the Department of Defense Breast Cancer Research Program to Y.W.

\section{REFERENCES}

Abe H, Engler D, Molitch ME, Bollinger-Gruber J, Reichlin S 1985 Vasoactive intestinal peptide is a physiological mediator of prolactin release in the rat. Endocrinology 116:1383-1390

Allen JD, Verhoeven E, Domen J, van der Valk M, Berns A 1997 Pim-2 transgene induces lymphoid tumors, exhibiting potent synergy with c-myc. Oncogene 15:1133-1141

Bartsch J, Truss M, Bode J, Beato M 1996 Moderate increase in histone acetylation activates the mouse mammary tumor virus promoter and remodels its nucleosome structure. Proc Natl Acad Sci USA 93:10741-10746

Baytel D, Shalom S, Madgar I, Weissenberg R, Don J 1998 The human Pim-2 proto-oncogene and its testicular expression. Biochim Biophys Acta 1442:274-285

Cato AC, Miksicek R, Schutz G, Arnemann J, Beato M 1986 The hormone regulatory element of mouse mammary tumour virus mediates progesterone induction. EMBO J 5:2237-2240 
Chang W, Hubbard SC, Friedel C, Ruley HE 1993 Enrichment of insertional mutants following retrovirus gene trap selection. Virology 193:737-747

Chen Z, Brand NJ, Chen A, Chen SJ, Tong JH, Wang ZY, Waxman S, Zelent A 1993 Fusion between a novel Kruppel-like zinc finger gene and the retinoic acid receptor-alpha locus due to a variant $\mathrm{t}(11 ; 17)$ translocation associated with acute promyelocytic leukaemia. EMBO J 12:1161-1167

David G, Alland L, Hong SH, Wong CW, DePinho RA, Dejean A 1998 Histone deacetylase associated with $\mathrm{mSin} 3 \mathrm{~A}$ mediates repression by the acute promyelocytic leukemia-associated PLZF protein. Oncogene 16:2549-2556

Dong S, Zhu J, Reid A, Strutt P, Guidez F, Zhong HJ, Wang ZY, Licht J, Waxman S, Chomienne C, Chen Z, Zelent A, Chen SJ 1996 Amino-terminal protein-protein interaction motif (POZ-domain) is responsible for activities of the promyelocytic leukemia zinc fingerretinoic acid receptor-alpha fusion protein. Proc Natl Acad Sci USA 93:3624-3629

Doppler W, Groner B, Ball RK 1989 Prolactin and glucocorticoid hormones synergistically induce expression of transfected rat beta-casein gene promoter constructs in a mammary epithelial cell line. Proc Natl Acad Sci USA 86:104-108

Fambrough D, McClure K, Kazlauskas A, Lander ES 1999 Diverse signaling pathways activated by growth factor receptors induce broadly overlapping, rather than independent, sets of genes. Cell 97:727-741

Fanjul AN, Bouterfa H, Dawson M, Pfahl M 1996 Potential role for retinoic acid receptor-gamma in the inhibition of breast cancer cells by selective retinoids and interferons. Cancer Res 56:1571-1577

Feng ZM, Bardin CW, Chen CL 1989 Characterization and regulation of testicular inhibin beta-subunit mRNA. Mol Endocrinol 3:939-948

Fu SL, Waha A, Vogt PK 2000 Identification and characterization of genes upregulated in cells transformed by v-Jun. Oncogene 19:3537-3545

Fusco O, Querzoli P, Nenci I, Natoli C, Brakebush C, Ullrich A, Iacobelli S 1998 90K (MAC-2 $\mathrm{BP})$ gene expression in breast cancer and evidence for the production of $90 \mathrm{~K}$ by peripheralblood mononuclear cells. Int J Cancer 79:23-26

Goya L, Maiyar AC, Ge Y, Firestone GL 1993 Glucocorticoids induce a G1/G0 cell cycle arrest of Con8 rat mammary tumor cells that is synchronously reversed by steroid withdrawal or addition of transforming growth factor-alpha. Mol Endocrinol 7:1121-1132

Graham JD, Clarke CL 1997 Physiological action of progesterone in target tissues. Endocr Rev 18:502-519

Groner B, Altiok S, Meier V 1994 Hormonal regulation of transcription factor activity in mammary epithelial cells. Mol Cell Endocrinol 100:109-114

Groner B, Gouilleux F 1995 Prolactin-mediated gene activation in mammary epithelial cells. Curr Opin Genet Dev 5:587-594

Groshong SD, Owen GI, Grimison B, Schauer IE, Todd MC, Langan TA, Sclafani RA, Lange CA, Horwitz KB 1997 Biphasic regulation of breast cancer cell growth by progesterone: role of the cyclin-dependent kinase inhibitors, p21 and p27(Kip1). Mol Endocrinol 11:1593-1607

Harkin DP, Bean JM, Miklos D, Song YH, Truong VB, Englert C, Christians FC, Ellisen LW, Maheswaran S, Oliner JD, Haber DA 1999 Induction of GADD45 and JNK/SAPKdependent apoptosis following inducible expression of BRCA1. Cell 97:575-586

Heximer SP, Watson N, Linder ME, Blumer KJ, Hepler JR 1997 RGS2/G0S8 is a selective inhibitor of Gqalpha function. Proc Natl Acad Sci USA 94:14389-14393

Horwitz KB 1992 The molecular biology of RU486. Is there a role for antiprogestins in the treatment of breast cancer? Endocr Rev 13:146-163 
Hynes N, van Ooyen AJ, Kennedy N, Herrlich P, Ponta H, Groner B 1983 Subfragments of the large terminal repeat cause glucocorticoid-responsive expression of mouse mammary tumor virus and of an adjacent gene. Proc Natl Acad Sci USA 80:3637-3641

Jelinsky SA, Samson LD 1999 Global response of Saccharomyces cerevisiae to an alkylating agent. Proc Natl Acad Sci USA 96:1486-1491

Kondratyev AD, Chung KN, Jung MO 1996 Identification and characterization of a radiationinducible glycosylated human early-response gene. Cancer Res 56:1498-1502

Korbelik M, Naraparaju VR, Yamamoto N 1998 The value of serum alpha-N-acetylgalactosaminidase measurement for the assessment of tumour response to radio- and photodynamic therapy. Br J Cancer 77:1009-1014

Lambert JR, Nordeen SK 1998 Steroid-selective initiation of chromatin remodeling and transcriptional activation of the mouse mammary tumor virus promoter is controlled by the site of promoter integration. J Biol Chem 273:32708-32714

Lane NE, Lukert B 1998 The science and therapy of glucocorticoid-induced bone loss. Endocrinol Metab Clin N Am 27:465-483

Lange CA, Richer JK, Horwitz KB 1999 Hypothesis: progesterone primes breast cancer cells for cross-talk with proliferative or antiproliferative signals. Mol Endocrinol 13:829-836

Lieberman BA, Bona BJ, Edwards DP, Nordeen SK 1993 The constitution of a progesterone response element. Mol Endocrinol 7:515-527

Lippman M, Bolan G, Huff K 1976 The effects of glucocorticoids and progesterone on hormoneresponsive human breast cancer in long-term tissue culture. Cancer Res 36:4602-4609

McKay LI, Cidlowski JA 1999 Molecular control of immune/inflammatory responses: interactions between nuclear factor-kappa B and steroid receptor-signaling pathways. Endocr Rev 20: 435-459

McKenna NJ, Lanz RB, O’Malley BW 1999 Nuclear receptor coregulators: cellular and molecular biology. Endocr Rev 20:321-344

Miller AD, Buttimore C 1986 Redesign of retrovirus packaging cell lines to avoid recombination leading to helper virus production. Mol Cell Biol 6:2895-2902

Musgrove EA, Lee CS, Sutherland RL 1991 Progestins both stimulate and inhibit breast cancer cell cycle progression while increasing expression of transforming growth factor alpha, epidermal growth factor receptor, c-fos, and c-myc genes. Mol Cell Biol 11:5032-5043

Nakamura H, Masutani H, Tagaya Y, Yamauchi A, Inamoto T, Nanbu Y, Fujii S, Ozawa K, Yodoi J 1992 Expression and growth-promoting effect of adult T-cell leukemia-derived factor. A human thioredoxin homologue in hepatocellular carcinoma. Cancer 69:2091-2097

Nakamura H, Nakamura K, Yodoi J 1997 Redox regulation of cellular activation. Annu Rev Immunol 15:351-369

Nishiyama A, Matsui M, Iwata S, Hirota K, Masutani H, Nakamura H, Takagi Y, Sono H, Gon Y, Yodoi J 1999 Identification of thioredoxin-binding protein-2/vitamin D(3) up-regulated protein 1 as a negative regulator of thioredoxin function and expression. $\mathrm{J}$ Biol Chem 274:21645-21650

Nishizuka M, Honda K, Tsuchiya T, Nishihara T, Imagawa M 2001 RGS2 promotes adipocyte differentiation in the presence of ligand for peroxisome proliferator-activated receptor gamma. J Biol Chem 276:29625-29627

Nomura S, Hashmi S, McVey JH, Ham J, Parker M, Hogan BL 1989 Evidence for positive and negative regulatory elements in the $5^{\prime}$-flanking sequence of the mouse sparc (osteonectin) gene. J Biol Chem 264:12201-12207

Nordeen SK, Kuhnel B, Lawler-Heavner J, Barber DA, Edwards DP 1989 A quantitative comparison of dual control of a hormone response element by progestins and glucocorticoids in the same cell line. Mol Endocrinol 3:1270-1278 
Oliveira-Dos-Santos AJ, Matsumoto G, Snow BE, Bai D, Houston FP, Whishaw IQ, Mariathasan S, Sasaki T, Wakeham A, Ohashi PS, Roder JC, Barnes CA, Siderovski DP, Penninger JM 2000 Regulation of T cell activation, anxiety, and male aggression by RGS2. Proc Natl Acad Sci USA 97:12272-12277

Payvar F, DeFranco D, Firestone GL, Edgar B, Wrange O, Okret S, Gustafsson JA, Yamamoto KR 1983 Sequence-specific binding of glucocorticoid receptor to MTV DNA at sites within and upstream of the transcribed region. Cell 35:381-392

Pietzsch A, Buchler C, Aslanidis C, Schmitz G 1997 Identification and characterization of a novel monocyte/macrophage differentiation-dependent gene that is responsive to lipopolysaccharide, ceramide, and lysophosphatidylcholine. Biochem Biophys Res Commun 235:4-9

Porterfield SP 1996 Endocrine Physiology. St. Louis: Mosby-Year Book; 139-146

Pratt WB, Toft DO 1997 Steroid receptor interactions with heat shock protein and immunophilin chaperones. Endocr Rev 18:306-360

Prior JC 1990 Progesterone as a bone-trophic hormone. Endocr Rev 11:386-398

Rackoff PJ, Rosen CJ 1998 Pathogenesis and treatment of glucocorticoid-induced osteoporosis. Drugs Aging 12:477-484

Raffo P, Emionite L, Colucci L, Belmondo F, Moro MG, Bollag W, Toma S 2000 Retinoid receptors: pathways of proliferation inhibition and apoptosis induction in breast cancer cell lines. Anticancer Res 20:1535-1543

Reddy S, DeGregori JV, von Melchner H, Ruley HE 1991 Retrovirus promoter-trap vector to induce lacZ gene fusions in mammalian cells. J Virol 65:1507-1515

Richer JK, Jacobsen BM, Manning NG, Abel MG, Wolf DM, Horwitz KB 2002 Differential gene regulation by the two progesterone receptor isoforms in human breast cancer cells. J Biol Chem 277:5209-5218

Robinson GW, Hennighausen L 1997 Inhibins and activins regulate mammary epithelial cell differentiation through mesenchymal-epithelial interactions. Development 124:2701-2708

Russ AP, Friedel C, Ballas K, Kalina U, Zahn D, Strebhardt K, von Melchner H 1996 Identification of genes induced by factor deprivation in hematopoietic cells undergoing apoptosis using gene-trap mutagenesis and site-specific recombination. Proc Natl Acad Sci USA 93:15279-15284

Schafer H, Lettau P, Trauzold A, Banasch M, Schmidt WE 1999 Human PACAP response gene 1 (p22/PRG1): proliferation-associated expression in pancreatic carcinoma cells. Pancreas $18: 378-384$

Scheidereit C, Geisse S, Westphal HM, Beato M 1983 The glucocorticoid receptor binds to defined nucleotide sequences near the promoter of mouse mammary tumour virus. Nature 304:749752

Shaknovich R, Yeyati PL, Ivins S, Melnick A, Lempert C, Waxman S, Zelent A, Licht JD 1998 The promyelocytic leukemia zinc finger protein affects myeloid cell growth, differentiation, and apoptosis. Mol Cell Biol 18:5533-5545

Siderovski DP, Heximer SP, Forsdyke DR 1994 A human gene encoding a putative basic helix-loop-helix phosphoprotein whose mRNA increases rapidly in cycloheximide-treated blood mononuclear cells. DNA Cell Biol 13:125-147

Thackray VG, Lieberman BA, Nordeen SK 1998 Differential gene induction by glucocorticoid and progesterone receptors. J Steroid Biochem Mol Biol 66:171-178

Thornton JW 2001 Evolution of vertebrate steroid receptors from an ancestral estrogen receptor by ligand exploitation and serial genome expansions. Proc Natl Acad Sci USA 98:5671-5676

von Melchner H, Reddy S, Ruley HE 1990 Isolation of cellular promoters by using a retrovirus promoter trap. Proc Natl Acad Sci USA 87:3733-3737

von Melchner H, Ruley HE 1989 Identification of cellular promoters by using a retrovirus promoter trap. J Virol 63:3227-3233 
Wan Y, Nordeen SK 2002a Identification of genes differentially regulated by glucocorticoids and progestins using a Cre/loxP mediated retroviral promoter-trapping strategy. J Mol Endocrinol 28:177-192

Wan Y, Nordeen SK 2002b Overlapping but distinct gene regulation profiles by glucocorticoids and progestins in human breast cancer cells. Mol Endocrinol 16:1204-1214

Westin S, Rosenfeld MG, Glass CK 2000 Nuclear receptor coactivators. Adv Pharmacol 47:89-112

Yamamoto N, Naraparaju VR, Asbell SO 1996 Deglycosylation of serum vitamin D3-binding protein leads to immunosuppression in cancer patients. Cancer Res 56:2827-2831

Yang X, Young LH, Voigt JM 1998 Expression of a vitamin D-regulated gene (VDUP-1) in untreated- and MNU-treated rat mammary tissue. Breast Cancer Res Treat 48:33-44

Yeyati PL, Shaknovich R, Boterashvili S, Li J, Ball HJ, Waxman S, Nason-Burchenal K, Dmitrovsky E, Zelent A, Licht JD 1999 Leukemia translocation protein PLZF inhibits cell growth and expression of cyclin A. Oncogene 18:925-934

Yip-Schneider MT, Lin A, Marshall MS 2001 Pancreatic tumor cells with mutant K-ras suppress ERK activity by MEK-dependent induction of MAP kinase phosphatase-2. Biochem Biophys Res Commun 280:992-997

Ziegler R, Kasperk C 1998 Glucocorticoid-induced osteoporosis: prevention and treatment. Steroids 63:344-348 